\title{
The text of Jude 4
}

\author{
C H Landon
}

University of Stellenbosch

\begin{abstract}
The article analyses three variation units and one singular reading from the text of Jude 4. Following the rationale of thoroughgoing eclecticism, it concentrates on internal evidence. The most problematic variation unit

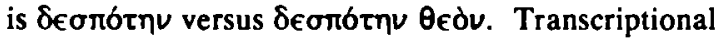
arguments can be advanced in favour of either of these variants. To resolve the conflicting transcriptional evidence, an 'etymological narrative' is provided to establish the Attic and Judaeo-Hellenic background of the word $\delta$ eorórnv as a metaphor applicable to the gods or to God. The etymological narrative and other intrinsic arguments suggest that $\delta \in \sigma \pi \delta \eta^{\prime} v$ refers to God, and that therefore an eclectic preference for the variant $\delta \epsilon \sigma \pi \delta t \eta v \theta \epsilon \delta \nu$ can be expressed.
\end{abstract}

\section{INTRODUCTION}

Despite the fact that '[c]onsidering the brevity of Jude, the textual critical problems are numerous and difficult' (Bauckham 1988:3792), thus far only four verses in Jude have generated text-critical discussions in journals and edited monographs. ${ }^{1}$ Albin's (1962) Swedish text-critical analysis of Jude as a whole remains the seminal work. Five factors can be enumerated in favour of a modern reappraisal of the text-critical problems in Jude as a whole:

* The publication of $p^{72}$ and $p^{74}$;

- The publication of $p^{78}$;

- The financial assistance of the Centre for Science Development (HSRC, South Africa) towards this research is bereby acknowledged. 
- The need to expand on Kubo's study of some of the variation units in Jude (Kubo 1965); the publication of The Greek New Testament according to the Majority Text (hereafter GNTMT); and

- The publication of much pioneering material relating to exegesis, rhetoric and style in Jude during the last three decades.

Albin's study of Jude predates only the first of these factors. It should be realized in particular that exegesis, rhetoric and style are all factors which can influence decisively any evaluation of internal evidence relating to a given variation unit. (The term 'variation unit' connotes the definition given by Epp 1976a:172-173). It therefore follows that there is a need for a text-critical study of Jude to update Albin's study by consulting (among other works) Bauckham's exegesis of Jude (1983), Watson's rhetorical study of Jude (1988), Ellis on prophecy and hermeneutic in Jude (1978a: 221-236), and Charles on literary artifice in Jude (1991a:106-124). The aim of this article is to examine three variation units and one singular reading from the text of Jude 4.2

The Epistle of Jude was not written in a cultural vacuum. It was written by someone with a wide reference frame of intra- and extra-canonical source material at his disposal. Jude 4 functions simultaneously as the narratio in the writer's Graeco-Roman rhetorical framework (Watson 1988:43) and as the introduction to a 'carefully composed piece of formal exegesis in the style of the Qumran pesharim ... which [can be called] a midrash' (Bauckham 1988:303). Following Ellis (1978a:221236), Bauckham explains that verses 4-19 in Jude contain the midrash, which consists of four main 'texts', each of which is followed by a 'commentary'. The strategy of the writer in exploiting the techniques of Graeco-Roman rhetoric and midrash exegesis in the same verse highlights the value of not being deliberately selective in our examination of source material relating to the internal evidence in this article.

\section{METHODOLOGICAL CONSIDERATIONS}

The methodological approach adopted in this article presupposes acceptance of the view of thoroughgoing eclectics such as Kilpatrick and Elliott that any analysis of variant readings should include a nuanced consideration of internal evidence only, (see for example, Elliott 1992:17-43). One of the main propositions upon which thoroughgoing eclecticism is based is that most deliberate changes in New Testament manuscripts had been made by A D 200 a proposition which Kilpatrick believed was validated by evidence from the early papyri, and by quotations in Irenaeus, Tertullian, Clement of Alexandria, Hippolytus, and the oldest Latin and Syriac versions (see Kilpatrick 1958:127-136; Flatt 1975:103; and Vogels 1955:162, cited in Elliott 
1992:26). It is this proposition which leads thoroughgoing eclectics to the position that there are at the moment no grounds for 'weighing' manuscripts according to external criteria, hence Elliott's statement that ' $[t]$ he age of a manuscript should be no guide to the originality of its text. One should not assume that a fourth-century manuscript will be less corrupt than say a twelfth-century one' (Elliott 1974:343).

One of the canons of external evidence demands that we examine 'a variant's support by the earliest manuscripts, or by manuscripts assuredly preserving the earliest texts' (Epp 1976b:243). $p^{72}$ is the oldest extant manuscript in which the text of Jude is contained. If one looks at Kubo's (1976:276-282) study of textual relationships in Jude, one can easily infer that Byzantine manuscripts contain variants which are preserved in $p^{72}$. As an example, Kubo notes that there is a $60 \%$ agreement between minuscule 1874 (dated tenth-century) and $p^{72}$. This is not to deny that Kubo's results also show a stronger relationship between $p^{72}$ and $B(72.30 \%)$, but how is it possible to 'weigh' $X$ more favourably than manuscripts such as minuscule 1874 when we learn from Kubo that the agreement between $p^{72}$ and $X$ is only $63 \%$ ? This state of affairs surely raises doubts about the merits of 'weighing' manuscripts according to the external canon which favours older manuscript.

The point about Byzantine readings existing in the earliest papyri is beyond dispute (see Sturz 1984:145-160; see also Elliott 1988:250-258, esp 257-258), and is worth expanding upon here. By way of illustration, an example of $p^{72}$ being supported by Byzantine manuscript against $X$ and $B$ occurs in Jude 22-23. Two texts, each with its own variations, exist: a two-clause text and a three-clause text. $p^{72}$ contains

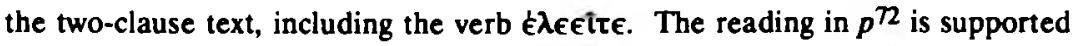

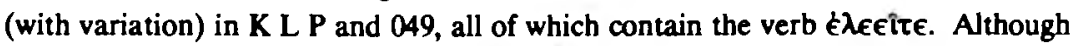
$B$ also has the two-clause text, it has $\epsilon \lambda \in \hat{\epsilon} t \epsilon$ instead of $\dot{\epsilon} \epsilon \in \hat{i} \tau \epsilon$, and if we accept Osburn (1972:141) and Birdsall (1963:397), the reading in B is a conflated corruption. The three clause reading which is found in $X$ is also conflate (Birdsall 1963: 397). The point here is not necessarily that we should accept the views of Birdsall and Osburn on Jude 22-23 (other critics disagree with their conclusions) but that our example demonstrates that Byzantine readings are to be found in early papyri, and that conflated readings can be found in older manuscript such as $X$ and $B$.

Other factors which have caused thoroughgoing eclectics to minimize reliance on external evidence may be enumerated as follows: (1) we do not have a genealogical history of the New Testament text (see Elliott 1992:36-37); (2) New Testament manuscripts have such a mixed character that one cannot discover a definite archetype based on clear lines of descent (see Elliott 1992:27; although on mixture in the paryri see Petzer 1986:21-22); (3) corruption can be found in all manuscripts, and older manuscripts such as $X$ and $B$ are as a result not as reliable as was once imagi- 
ned (see Elliott 1992:27); and (4) evidence presented in Professor Kilpatrick's (1965:189-206) contribution to the MacGregor memorial volume shows us that the Syrian text should no longer be judged according to prejudices which have persisted from the time of Westcott and Hort (the term 'Syrian text' as used in this article is that used by Kilpatrick [1965:189]).

This article does not attempt to prove or disprove the theory of textual transmission which gave rise to thoroughgoing eclecticism, nor does it attempt to deal with objections to thoroughgoing eclecticism: it attempts to illustrate the practical application of thoroughgoing eclecticism to a given New Testament verse. Jude 4 was chosen to show that the problem of colliding internal evidence (in this case, conflicting transcriptional evidence concerning the first variation unit below) need not necessarily present an insurmountable problem.

\section{NESTLE-ALAND TEXT (NA26)}

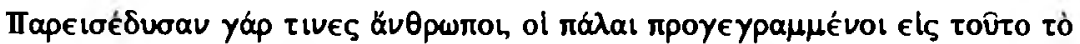

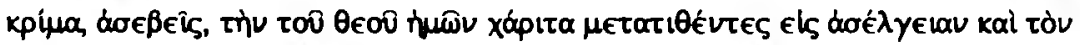

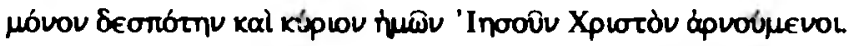

\section{MAJORITY TEXT (GNTMT)}

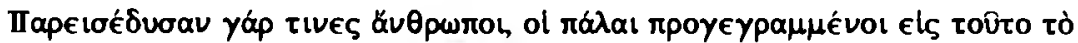

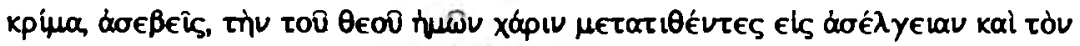

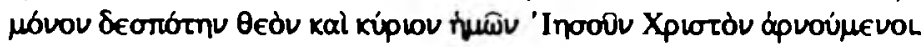

\section{TEXT-CRITICAL APPARATUS}

rapeloedumoav B C

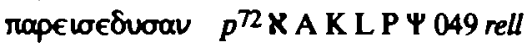

крчща $p^{72}$ A B CK L P 049 rell

ктриүна $\Psi$

xapeiтa $p^{72}$

xapita A B

xapiv X C K L P $\Psi 04905601420251$ rell

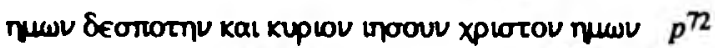

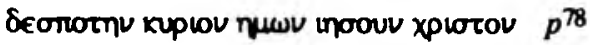

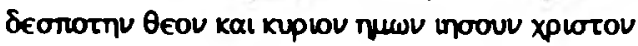




\author{
K L P $\Psi 0490560142$ \\ 972554215822298 \\ syph.b Oectrat Thphyl \\ Seorotnu kai kuplou пuwv inoouv xplotov \\ × A B C 025133368188104 \\ 181218307326337424431 \\ 436453467610642808915 \\ 92711751311182918371845 \\ $187418981908 \mathrm{vg}$ sa arm aeth \\ Lcf Ephr Did CyrA Ps-Chr
}

\title{
6. THE FIRST VARIATION UNTT
}

The main text-critical problem in Jude 4 is whether we should prefer the variant $\delta$ Eorómv as read in $p^{78} \times$ A B C 0251 and others, or whether we should choose the variant $\delta \in \sigma \pi o t n v \theta \epsilon \delta \nu$, which is preserved in the Syrian text.

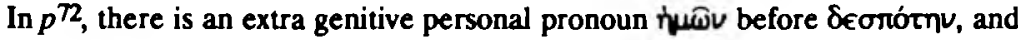
we also have word-order deviation. This raises a question: Can we cite the singular reading in $p^{72}$ as support for the mainstream Alexandrian variant $\delta$ eorótnv kal

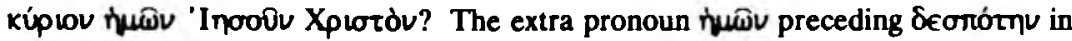
$p^{72}$ need not be considered a word-order infringement, since we know from Turner (1963:189) that it is possible to place a genitive pronoun either before or after an

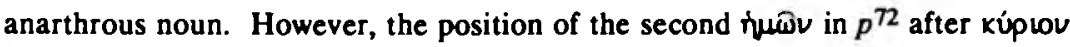
'Inoôv Xpıotov is cause for concern, since according to Blass and Debrunner $(1961: 249, \$ 473)$ it is usual for a pronoun to separate nouns which belong together

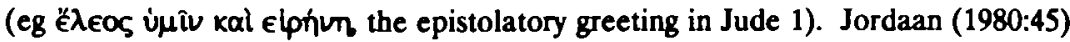
ascribes the position of the unemphatic pronoun in a similar example ( $x$ óp rs i $\mu$ iv kal eipinum in Galatians 1:3) strictly to a tendency in Koine Greek for unemphatic pronouns (such as our nuwv in $p^{72}$ ) to appear second in the word order of a sentence or clause. Turner (1963:190) says that on rare occasions, an unemphatic pronoun can appear before two nouns to save repetition (eg in $L k 12: 35$ and in Jn 11:48). But the position of $p^{72}$ 's unemphatic pronoun tuw Xprotov is certainly not in harmony with the pronominal tendencies in Koine Greek mentioned above. The singular reading in $p^{7}$ is therefore at best only a tentative citation in favour of the mainstream Alexandrian variant.

Commentators and textual critics who have looked at this problem have invariably defined it in terms of the ambiguous nature of the word $\delta$ eorotnv. (See, for example, Fuchs \& Reymond 1980:160; Kubo 1965:140; and Metzger 1971:723.) 
Metzger's textual commentary indicates that $\delta \in \sigma \pi \delta$ tnv is the better of the two variants because of the transcriptional likelihood that the reading $\delta \in \sigma \pi \delta$ trv $\theta \in \dot{v} v$ as preserved in the Syrian text has $\theta$ eòv appended to disambiguate the sentence, in view of the fact that $\delta$ eorornu could refer either to Jesus Christ or to God. However, nobody has yet considered the transcriptional case to be made for the reading

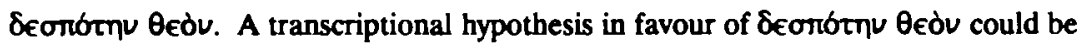
this: (1) developments in palaeography such as the use of nomina sacra, the existence of palimpsests and the transition from uncial to minuscule script all suggest that there was constant pressure upon ancient scribes to economize (see, for example, Metzger 1968:11-14); (2) beorbrnv Gedv in Jude 4 may have been shortened to $\delta \in \sigma \pi \delta$ rnv by a scribe who felt that because $\delta \in \sigma \pi \delta$ tnu was a known metaphorical

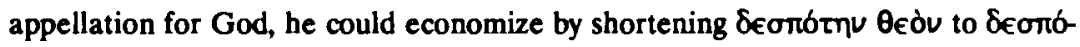
tnu without losing the meaning of the original reading. We now have a situa-tion which is familiar to thoroughgoing eclectics: clashing internal evidence, engen-dered by our conflicting transcriptional evidence. The intrinsic evidence which follows is provided as an attempt at arbitration, in order to enable us to consider whether there are grounds for opting for the reading $\delta \in \sigma \pi \delta$ rnv $\theta \in \dot{d} v$ as preserved in the Syrian text.

The first part of this intrinsic evidence consists of a narrative attempt to sketch the etymology of the word $\delta$ eorberns, with the focus specifically on the use of this word in the context of its metaphorical application to deity by Attic Greek writers, and in the context of its metaphorical application to the Deity by Judaeo-Hellenic writers.

In Euripides (Hip 88-89) we find the following reference to the gods:

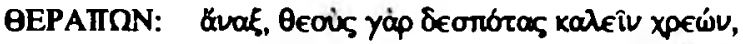

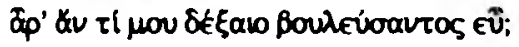

Barrett (1964:176) supplies the background to the servant's speech here. The old servant uses the term avaf to address Hippolytus, who has just been praying to the goddess Artemis, but who has ignored Aphrodite. Because the servant is devout, he is upset by the failure of Hippolytus to pay homage to Aphrodite. Hippolytus has twice addressed Artemis as $\delta$ éorowa in Hip:74 and Hip:82. Now the old servant scrupulously avoids addressing Hippolytus as $\delta e \sigma n 6 \tau \alpha$ to underscore his view that the expressions $\delta$ éonouva and $\delta \in \sigma \pi \delta \tau \alpha$ (used metaphorically) should be reserved for the gods. When addressing a god, the Attic Greek worshipper would humble 
himself by using the term $\delta \in \sigma \pi \delta$ ra, an address which refers metaphorically to the god as a 'master', and which connotes the implied metaphorical status of the worshipper as a 'slave'.

This distinctive metaphorical code, whereby the gods alone may be called 'masters', is alluded to by Xenophon (An 3.2.13):

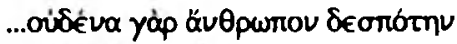

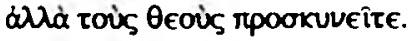

...for to no human creature do you pay

homage as master, but to the gods alone.

(tr by Brownson 1968:203)

The metaphorical reference to the gods as masters is also contained in Plato (Euthyd 302D):

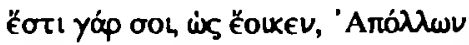

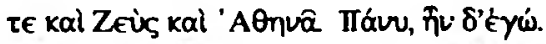

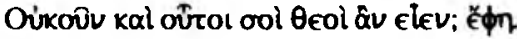

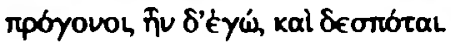

You have, it seems, Appolo and Zeus and Athena.

Certainly, I said.

Then these must be your gods? he said.

My ancestors, I said, and lords. ('lords' = masters)

(tr by Lamb 1977:489-490)

Even when the person praying, the god or goddess being prayed to, and the very act of prayer are all ridiculed by the Attic satirist Aristophanes (Wasps 389-394), there is no wavering from the term $\delta$ eororns as the correct form of address for a deity:

ФIAOKAESN:

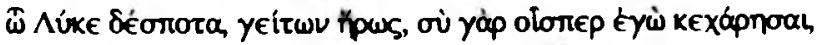

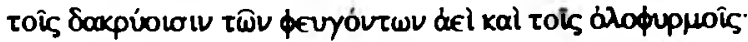

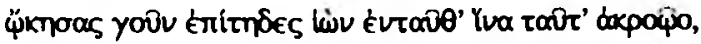

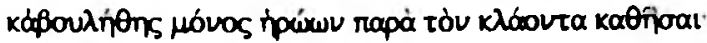

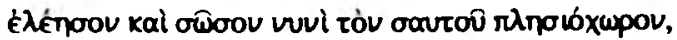

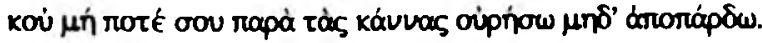

PHILOKLEON [praying]:

O Lord Lycus, thou Hero who art my

neighbour, forasmuch as thou delightest 
in the same things as $I$, in the tears and lamentations

of each day's defendants - at least you went and set up home there on purpose to hear them, and you are the only Hero who has chosen to take his seat near a crying man

- O take pity now on me who dwell close to thee, and save me, and I vow never to piss or fart beside your wicker fence.

(tr by Sommerstein 1983:41)

Moving from polytheistic to monotheistic writers, we find references to $\delta$ eorótns as a metaphor for God in Flavius Josephus (Ant 18.23) and (BJ 7.323-325) and Philo (Mut Nom 21-22). The chronological proximity of both of these writers to the time of Christ's life (Josephus was born in 37 or $38 \mathrm{AD}$; Philo was born in about $30 \mathrm{BC}$ ) means that we should pay close attention to the contexts which situate their use of the word $\delta$ eorotns. The quotations which appear immediately below are from Flavius Josephus:

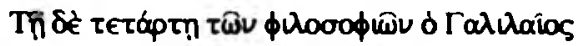

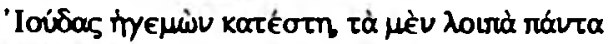

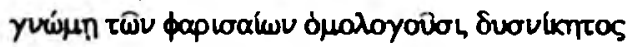

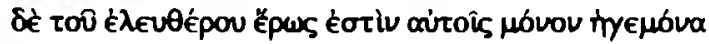

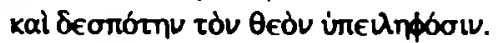

As for the fourth of the philosophies, Judas the Galilaean set himself up as leader of it. This school agrees in all other respects with the opinions of the Pharisees, except that they have a passion for liberty that is almost unconquerable, since they are convinced that God alone is their leader and master.

(Ant 18.23, tr by Feldman 1965:20-21)

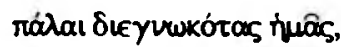

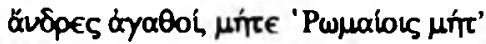

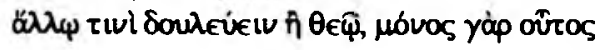

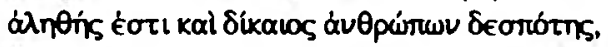

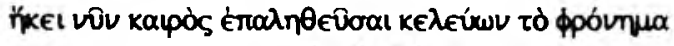

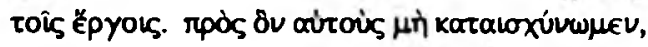

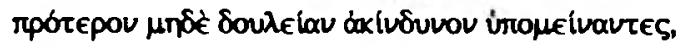




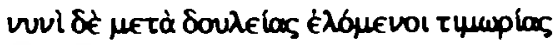

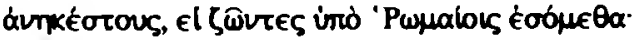

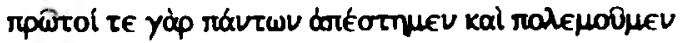

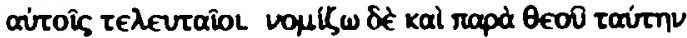

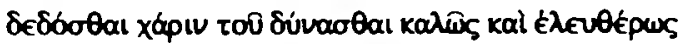

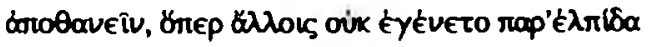
xparnteî́oiv.

Long since, my brave men, we determined neither to serve the Romans nor any other save God, for he alone is man's true and righteous lond; and now the time is come which bids us verify that resolution by our actions.

At this crisis let us not disgrace ourselves; we who in the past refused to submit even to a slavery involving no peril, let us not now, along with slavery, deliberately accept the irreparable penalties awaiting us if we are to fall alive into Roman hands. For as we were the first of all to revolt, so are we the last in arms against them. Moreover, I believe that it is God who has granted us this favour, that we have it in our power to die nobly and in freedom a privilege denied to others who have met with unexpected defeat.

(BJ 7.323-325, tr by Thackeray 1961:594-597)

In the quotation from $B \mathrm{~J}$ above, we have a complex treatment of the twin motifs of slavery and freedom, motifs which are linked to the notion of the fforótns as Deity in a way which represents a departure from Attic authors. The conventional slave-

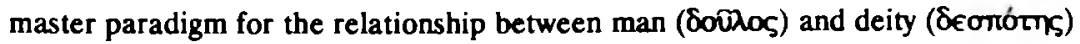
is somewhat reformulated. In place of the idea that man must lower himself to the metaphorical level of a slave when praying to the gods is the notion that loyalty to God will be rewarded by freedom from the literal slavery of the Roman occupation. However, in another respect, Josephus is loyal to the tradition visible in Euripides and Xenophon whereby the term \&eorórns as a metaphorical appellation for deity carries with it an exclusivity which binds it to a very specific semantic application. By 'exclusivity' is meant that $\delta$ eorotns, as a metaphor, applies exclusively to the gods or to God. In Josephus (Ant 18.23) and (BJ 7.323-325) respectively, the phrases 'God alone is their leader and master' and 'God ... alone is man's true and right- 
eous lord' imply a warning: God is exclusively man's $\delta \in \sigma \pi o ́ t n s$ - the Romans may not be deemed 'masters'. This idea of exclusivity echoes our Attic writers, and it foreshadows the context in which the word \&eorormv is used in Jude 4. The writer's message in Jude 4 can be paralleled with the waming in Josephus mentioned above: instead of the warning that the Romans may not be deemed 'masters', in Jude 4 we

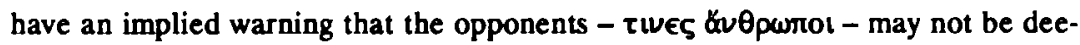

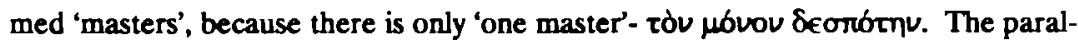
lel is visible in as much as Josephus and Jude both distinguish a contrast between implied false masters (either Romans or opponents) on the one hand, and the one true master, God, on the other.

The use of the term $\delta$ eotototns as a reference to God also appears in Philo (Mut Nom 21-22):

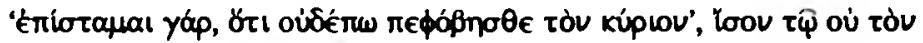

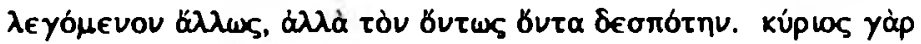

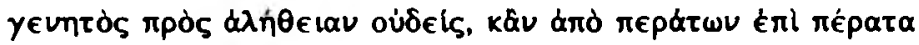

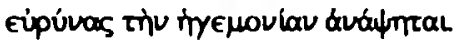

'For I know that ye have not yet feared the Lord' (Ex 9:30), meaning that Lord who is not merely socalled but is Lord [Master] in very truth. For none that is created is truly a Lord, though he be invested with a rule that spreads from pole to pole.

(tr by Colson \& Whitaker 1934:155)

Philo's statement that 'none that is created is truly a Lord' mirrors 'God alone is their leader and master' in Josephus (Ant 18.23). The phrases 'only God' and 'only Master' were standard formulae in Jewish and Christian writings to distinguish monotheism from non-Christian polytheism (Kelly 1969:252). Turning again to Jude 4, our problem phrase reads as follows:

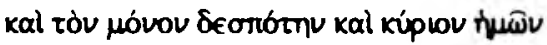

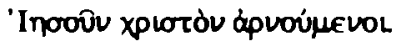

Although the views of Kelly (1969:252), Fuchs and Reymond (1980:160), Green

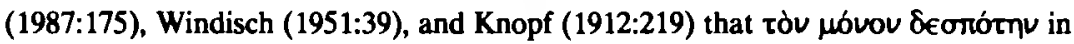
Jude 4 is a reference to God, all presuppose that $\delta$ eorótnv is the better of the two variants, their preferences can be regarded as indirect arguments for preferring $\delta \in \sigma-$ $\pi \delta$ rqu $\theta \in \dot{d} v$ as the better variant. Their views are understandable in the light of Jude's preference for using Judaic source material (see Charles 1990:109-124 and Charles 1991b:130-145). We know from Charles that Jude's source material includes Old Testament authors and extra-canonical Jewish source material: is it so in- 


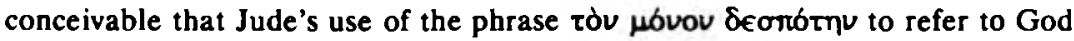
should echo a standard Judaeo-Hellenic formula?

There are three intrinsic considerations which can be added to the argument ( $\delta$ eonotnv $=$ God) which is implied by our etymological narrative. Firstly, the proposition should be considered that the word $\delta$ eororns is not used of Christ anywhere in the New Testament other than in 2 Peter 2:1. Bauckham (1983:142) has argued convincingly that 2 Peter is dependent upon Jude on the grounds of Jude's more polished and tightly constructed literary structure, and that the word $\delta \in \sigma$ rotns in 2 Peter 2:1 is borrowed from Jude (Bauckham 1983:240). However, this

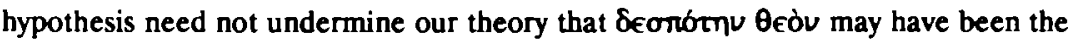

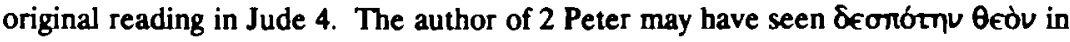
Jude 4, and decided for his own reasons to break with Jude's traditional usage. This would account for the appearance of $\delta$ eorónv in 2 Peter 2:1 as an apparent reference to Jesus Christ.

Secondly, as has been pointed out by Fuchs and Reymond (1980:160), elsewhere in the Epistle of Jude the writer is careful to make the distinction between Jesus Christ and God, and in verse 25 he specifically uses the adjective róvos to qualify Oeòs:

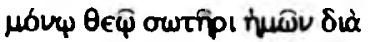

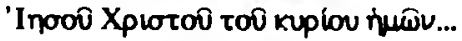

It would seem that the epithets used of God and of Jesus Christ in Jude 4, 21 and 25 follow the pattern which has wide distribution throughout the New Testament, with God being qualified by $\mu$ óvos, and Jesus Christ being referred to as kiplos rather than \&eoróms. Elliott (1988:255) has mentioned the importance of set expressions in New Testament usage as a factor in determining the originality of a given reading. Although our Syrian variant $\delta \in \sigma \pi \delta$ tnv $\theta \epsilon \dot{v} v$ is not itself a fixed New Testament expression it can be seen as such in an indirect sense: (1) because the adjective

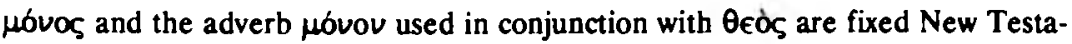

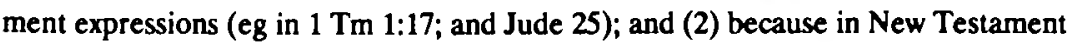
usage, the reference of $\delta \in \sigma \pi$ ónv to God is a fixed expression (eg in $\mathrm{Lk} 2: 29$; Ac 4:24; Rv 6:10; and $2 \operatorname{Tm} 2: 21$ ). Since there is no New Testament parallel for $\delta \in \sigma-$ rótrv $\theta \in o d v$ as a combination, ${ }^{3}$ the harmonization argument cannot be employed against the variant $\delta \in \sigma \pi o ́ t \eta v ~ \theta e o ̀ v$. Further, $\delta$ eqrótnv $\theta \in o ̀ v$ is self-evidently not a conflated reading.

Thirdly, there is the idea that the relationship between Jesus and his disciples need not necessarily be perceived as a 'slave-master' relationship. Voelz (1989:34) has made the suggestion that the way in which Jesus hands over authority to his disciples in Luke 9:1 signifies that they were in a rabbi-pupil relationship, not in a 
slave-master relationship. If this view is correct, then it decreases further the likeli-

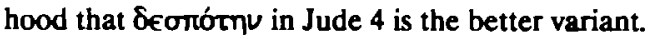

Bigg (1902:327), Bauckham (1983:39), Kistemaker (1987:375) and Bolkestein (1963:208-213) are all in favour of the view that $\delta$ eorotru in Jude 4 is a reference to Jesus Christ, a view which is based on the presupposition that $\delta \in \sigma \pi \delta$ inv is the better variant. In defence of this view, Bauckham cites Eusebius ( $H E$ 1.7.14), where there is a reference to Jewish people known as $\delta$ eoróouvol. Bauckham does not give us the full quotation or context of this citation, so it is provided here:

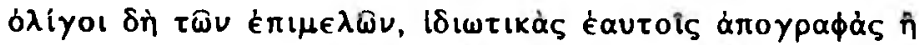

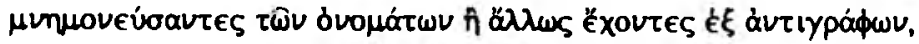

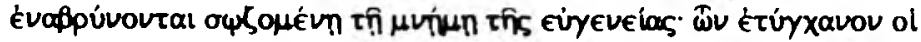

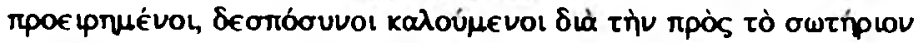

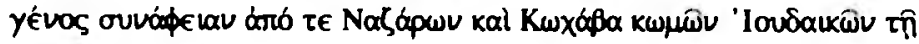

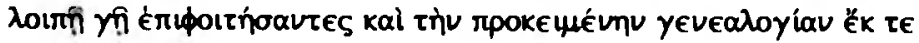

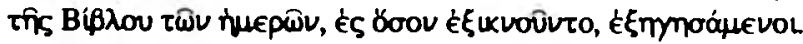

Now a few who were careful, having private records for themselves, either remembering the names or otherwise deriving them from copies, gloried in the preservation of the memory of their good birth; among these were those mentioned above, called desposyni, because of their relation to the family of the Saviour, and from the Jewish villages of Nazareth and Cochaba they traversed the rest of the land and expounded the preceding genealogy of their descent, and from the book of Chronicles so far as they went.

(HE 1.7.14, tr Lake 1953:63)

The background here concerns Jewish people whose birth certificates and other family records had been burned by Herod. To preserve the memory of their pure lineage, the members of some Jewish families memorized these records. The term deorbouvol is used in the citation above to underscore the point that certain Jews were of good stock. because of their family connections with to owtip Saviour - a word which appears to be a reference to Jesus, although Bauckham omits to tell us that to owrinpov could equally well refer to God, as it does in Jude 25. In view of the fact that Eusebius was born in about A D 260 and died in 339 or 340, what Bauckham provides us with is an argumentum e silentio that Jesus was referred to as $\delta$ eoriotns after his death, but there is no proof here that the term $\delta$ eororms was used as a reference to Jesus Christ during his lifetime.

Kistemaker's view (1987:375) that $\delta$ eorótnv in Jude 4 refers to Jesus Christ (again based upon the presupposition that $\delta \in \sigma \pi 6 \tau \eta v$ is the better variant) is some- 
what tentatively substantiated by the citation of a grammatical rule mentioned in Dana and Mantey (1967:147). Kistemaker says that '...in the Greek only one definite article precedes the nouns Sovereign [master] and Lord. The rule states that when one article controls two nouns the writer refers to one person'. The validity of this argument is questionable. It leaves us with an unanswered question: if the rule mentioned by Kistemaker is universally binding, then why is it that the Syrian rea-

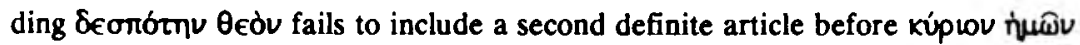
'Inoov̂ Xplotov, to indicate that kúpıv is separate from $\theta$ eòv, and to show that the first definite article concords not with both nouns but merely with the first one? Meanwhile, Dr Bauckham instances the same grammatical rule, but points out that kúplos often appears without an accompanying article, thus weakening Kistemaker's argument still further (see Bauckham 1990:302-303). Turner (1963:174) confirms that it is quite normal for kiplos to be anarthrous in the New Testament since, like $\theta \in o ́ s$, kúplos is near to being a proper noun.

\section{THE SECOND VARIATION UNTT}

With regard to the second variation unit mentioned in the introduction, xóptu is the accusative of $\chi \not \alpha \varphi \zeta$, with $\chi \not \alpha \rho ı \alpha$ an alternative accusative (Zerwick \& Grosvenor 1979:738). In this case, there would appear to be little justification for accepting the variant xópuv as published in Von Soden (1913:657), Merk (1964:789) and GNTMT.

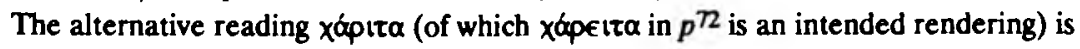
published as the accepted reading in NA26, GNT3, Vogels (1949:741), De Zwaan (1909:135), Westcott \& Hort (1901, hereafter WH), Tischendorf (1872:354) and H KAINH $\triangle$ IAOHKH (hereafter BFBS2). De Zwaan, Tischendorf and WH in particular all considered $\chi \alpha \alpha p t \tau \alpha$ to be the better variant even before the discovery and publication of $p^{72}$ and $p^{78}$, both of which lend extra support to xoptza. Internally, Epp's eighth canon (1976:243) is applicable as an explanation in favour of xópıtz: 'a variant's lack of conformity to parallel passages...'. In his famous essay on textual criticism, Housman (1922:1068) says '...scribes will alter a less familiar form to a more familiar, if they see nothing to prevent them'. Whereas xuptv is the usual

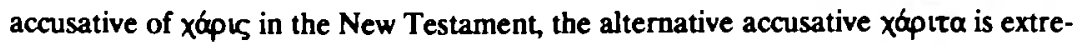
mely rare, occurring only in Jude 4 and Acts $24: 27$. It seems probable that in the case of Jude 4, $\chi \not x p ı \tau \alpha$ was altered to the more familiar $\chi \alpha \phi ı v$, and that therefore we should select $\chi$ óp $1 \tau \alpha$ as the better variant.

De Zwaan (1909:135) gives us another internal reason for choosing $x \not ́ p ı \tau \alpha$ in

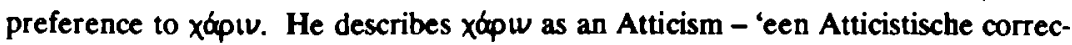
tie'. De Zwaan's judgement about $\chi$ ópl $v$ being an Atticism concords with that of Dr 
Elliott, who cites the Atticist grammarian Moeris to substantiate the observation that 'the Hellenistic form of the accusative [of Xópus] is Xápı $\tau \alpha$ and the Attic Xóplv'

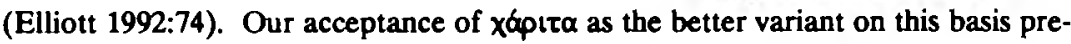
supposes acceptance of Kilpatrick's (1963:15-32) proposition that we should prefer Koine variants and reject their Attic equivalents. ${ }^{4}$

\section{THE THIRD VARIATION UNTT}

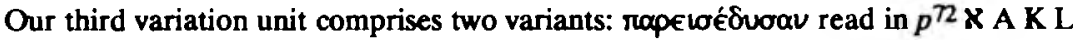
$P \Psi 049$ and others, and ropeloédumorv read in B and C. Both variants are aorist,

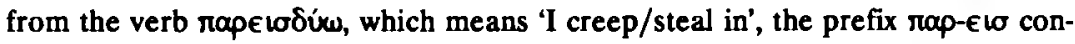
veying 'unawares' (Zerwick \& Grosvenor 1979:738). The difference between the

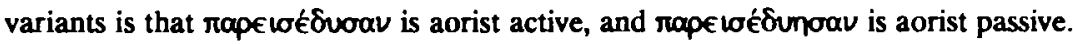
Internally, one argument in favour of ropeloé $\delta$ uno $\alpha$ is the notion that it could be the better reading because it is the harder reading (Kubo 1965:85). More convincing is Kubo's own counter-argument (1965:85) that, because the verb rapewofixw is mostly used in the middle, the probability is that scribes corrected the active

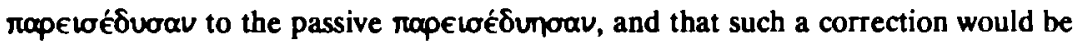
typical of B in particular. Kubo's preference for rapewédvorav is reflected by the appearance of the same variant in the following published texts: NA26, GNT3, GNTMT, Tischendorf (1872:354), Merk (1964:789), Vogels (1949:741), Von Soden (1913:657) and De Zwaan (1909:135). Only two editions consulted contain rap-

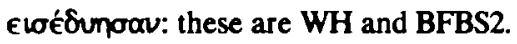

\section{THE SINGULAR READING KHPYIMA AND THE READING KPIMA}

The final issue to be dealt with in this article concerns the readings $x p i \mu a$, supported by $p^{72}$ A B C K L P 049 and others, and the singular reading kipuypa, which is read in $\Psi$. This time, there are no differences of opinion among text editors: they are at one that $x p i q a$ is the better of the two readings. The problem with the phrase touto to kpina is that it does not seem to fit the context of the passage; as Bratcher (1984:173) puts it, 'the expression this condemnation is a bit strange, since Jude has not mentioned any condemnation explicitly'. Bauckham (1983:36-37) provides more detail on the difficulties surrounding tovto to $\mathrm{kp}$ ina His suggestion is that tovto to xpiua refers forward to verses 5-7, verse 11 and verses 14-15. The context is that the intruders are destined for condemnation ( $v 4)$; cortain sins are ascribed to them (vv 5-19); and judgement will be meted out to them (vv 6 \& 15) (Green 1987:174). The word $x p i \mu a$ in verse 4 is morphologically close enough to $x p l o w$ in verses 6 and 
15 for them both to be identified as catchwords, the network of which is an established feature of the writer's style (Charles 1991a:112). These catchwords are not the product of an arbitrary impulse on the part of the author, but are 'the hallmark of the midrashic procedure' (Ellis 1978a:225). It is therefore possible to cite Epp's fourth internal canon (1976b:243) relating to internal evidence ('a variant's conformity to the author's style and vocabulary') in defence of kpira But what remains strange about the phrase tỗto tò $k p$ ina is that it seems to mark an abrupt change of direction from the previous verse - almost as if there is a verse missing between verse 3 and verse 4 - in the sense that for the writer to refer to this condemnation implies that it is not his first reference to condemnation, and yet there is no mention of condemnation prior to verse 4. This is perhaps why Bratcher $(1984: 173)$ refers to the strangeness of the expression tovto to $k p l \mu \alpha$. Perhaps the strangeness attri-

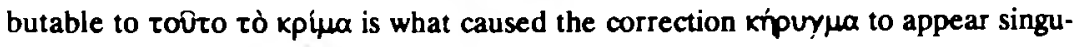

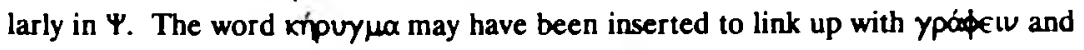
ypóuat in verse 3. Alternatively, it is possible to argue that the word kípuypa suits the immediate context of the verse. The word kipuy $\mu \alpha$ can be defined as 'the content of what is preached' (Louw \& Nida 1989, \$ 33.258). Schanz (1983:41-42) sees kripuyua, in the New Testament as a whole, as the 'good news' of the resurrection of Jesus Christ. If we translate the first part of verse 4 with knjpuypa in place of kplya, we have godless infiltrators who were ordained for the 'good news' long ago, but who transformed the grace of God into licentiousness. In other words, the infiltrators received the 'good news' long ago, but (by implication) they rejected it, just as they distorted the grace of God. For a singular reading (such as kipuyua here in Jude 4) to be considered as the original reading, according to Fee (1976:184) and Elliott (1978:103), the internal evidence in its favour must be decisive. In this case, internal evidence in favour of kipuy $\mu$ a is not decisive, so we must concord with the

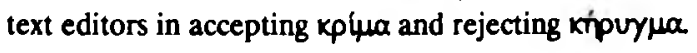

\section{CONCLUDING REMARKS}

In 1914, A C Clark wrote that 'a text is like a traveller who loses a piece of luggage every time he changes trains'. There are six intrinsic arguments which allow the

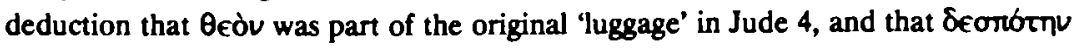
is a reference to God:

- Our etymological narrative illustrates that there is an established Attic and Judaeo-Hellenic tradition whereby the metaphorical application of the term $\delta$ enotrns is exclusively to deity or to the Deity, and that there is a strong likelihood that Jude is following this tradition; 
- Judaeo-Hellenic writers such as Philo and Josephus routinely use the terms $\mu$ wovos and $\delta \in \sigma \pi$ ótns in combination when referring to God: the qualification

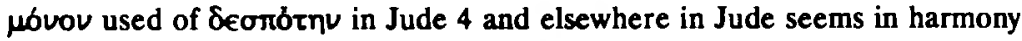
with this Judaeo-Hellenic usage;

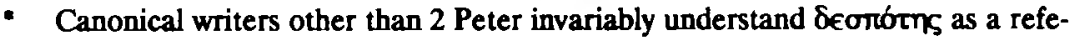
rence to God, not to Jesus Christ;

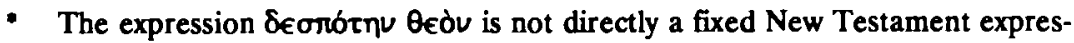
sion, but may be a fixed New Testament expression in an indirect sense;

- The relationship between Jesus and the disciples can be described as a rabbipupil rather than a slave-master relationship; and

- The grammatical rule cited by Kistemaker (1987) is inapplicable to Jude 4.

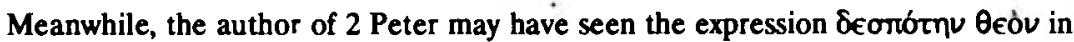
Jude, but decided to break with Jude's traditional usage and use $\delta \in \sigma \pi b \tau \eta v$ as a reference to Jesus Christ. In view of these intrinsic arguments, and the transcriptional possibility that $\delta \in \sigma \pi \delta \tau^{\prime} \nu \nu \theta \in \delta \nu$ may be the better variant, an eclectic prefe-

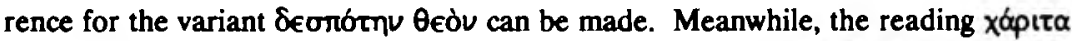
from our second variation unit is internally more probable than xáptv. The reading

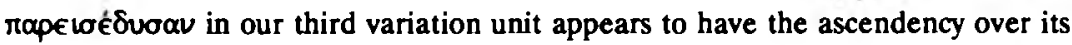
rival on internal grounds. Finally, in the absence of decisive internal support for the singular reading kripuy $\mu a$, we must accept $k p(\mu a$ in preference.

\section{Endnotes}

1. Dr J C Thom and Dr J H Petzer are both thanked for their comments on the first draft of this article, which is adapted from the fifth chapter of my doctoral thesis in progress entitled $A$ text-critical study of the epistle of Jude, based on the principles of thoroughgoing eclecticism. I am also indebted to Dr J K Elliott, reader in New Testament textual criticism at the University of Leeds, for sending me photostat copies of the text of Jude in: (1) the late Professor G D Kilpatrick's annotated personal copy of $H$ KAINH $\triangle \mathrm{I} A \Theta H K H$, and (2) Professor Kilpatrick's Greek-English Diglot for private circulation.

2. It should be stressed that my eclectic preference for the variant $\delta \in \sigma \pi \delta$ trnv $\theta \in o ̀ \nu$ as accepted by the editors of GNTMT is in no way an endorsement of the majority theory which gave rise to the publication of GNTMT. 
3. At Acts 4:24 the words $\delta \in \sigma \pi \sigma^{2} n v$ and $\theta$ eodu do not appear side by side as they do in Jude 4.

4. Some critics have reservations about Kilpatrick's proposition regarding Atticism (see, for example, Fee 1976:185-192 and Martini 1974:149-156). These reservations are countered by Elliott's claim that some scribes who were instrumental in producing New Testament manuscripts are likely to have heeded the rulings of the Attic grammarians Moeris and Phrynichus (see Elliott 1992:30). Further, Professor Metzger is known to have agreed with Professor Jordaan's proposal (1980) that there are firm differences between Attic and Koine Greek word order, and that these differences can help us choose between word order variants.

\section{Works cited}

Albin, C A 1962. Judasbrevet: Traditionen-Texten-Tolkningen. Lund: Hakan Ohlssons Boktryckeri.

Aland, K \& Aland, B 1989. The tert of the New Testament: An introduction to the critical editions and to the theory and practice of modern textual criticism. 2nd ed. Leiden: Brill.

Aland, K, et al (eds) 1975. The Greek New Testament. 3rd ed. London: United Bible Societies.

-- 1979. Novum Testamentum Graece. 26th ed. Stuttgart: Deutsche Bibelgesellschaft.

Anderson, H \& Barclay, W (eds) 1965. The New Testament in historical and contemporary perspective: Essays in memory of $G \mathrm{H} C \mathrm{MacGregor.} \mathrm{Oxford:} \mathrm{Blackwell.}$

Barrett, W S (ed) 1964. Euripides: Hippolytus, edited with an introduction and commentary. Oxford: Clarendon.

Bauckham, R J 1983. Jude, 2 Peter. Waco: Word.

-- 1988. The Letter of Jude: An account of research, in Haase, W (ed) 1988:3791. 3826.

-- 1990. Jude and the relatives of Jesus in the earty chunch. Edinburgh: Clark.

Bigg, C 1902. A critical and exegetical commentary on the epistles of St Peter and St Jude. Edinburgh: Clark.

Birdsall, J N 1963. The text of Jude in $p^{n}$. JThS 14, 394-399.

Black, M \& Smalley, W A (eds) 1974. On language, culture, and religion in honour of Eugene A Nida. The Hague \& Paris: Mouton. 
Blass, F \& Debrunner, A 1961. A Greek grammar of the New Testament and other eanty Christian literature. Chicago: Chicago University Press.

Bolkestein, M H 1963. De brieven van Petrus en Judas. Nijkerk: Callenbach.

Bratcher, R G 1984. A translator's guide to the letters from James, Peter and Jude. London: United Bible Saciety.

Brownson, C L (ed) 1968. Xenophon: Anabasis, Books 1-7. London: Heinemann. (Loeb Classical Library.)

Charles, J D 1990. 'Those' and 'these': The use of the Old Testament in the Epistle of Jude. JSNT 38, 109-124.

-.. 1991a. Literary artifice in the Epistle of Jude. $Z N W$ 82, 106-124.

- 1991b. Jude's use of pseudepigraphical source material as part of a literary strategy. NTS 37, 130-145.

Clark, A C 1914. The primitive text of the Gospels and Acts. Oxford: Clarendon .

Colson, F H \& Whitaker, G H (eds) 1934. Philo: De fuga et inventione; De mutatione nominum; De somniis. London: Heinemann. (Loeb Classical Library.)

Dana, H E \& Mantey, J R 1967. A manual grammar of the Greek New Testament. New York: Macmillan.

De Zwaan, J 1909. II Petrus en Judas. Leiden: Van Doesburg.

Diggle, J \& Goodyear, F R D (eds) 1972. The classical papers of A E Housman, vol 3. Cambridge: Cambridge University Press.

Ellioth, J K 1974. Can we recover the original New Testament? Theology 77, 338353.

--. (ed) 1976. Studies in the New Testament language and text: Essays in honour of George D Kilpatrick on the occasion of his sixty-fifth birthday. Leiden: Brill.

- 1978. In defence of thoroughgoing eclecticism in New Testament textual criticism. RestQ 21, 95-115.

- 1988. The text of Acts in the light of two recent studies. NTS 34, 250-258.

-- (ed) 1990. The principles and practice of New Testament textual criticism: Collected essays of G B Kilpatrick. Leuven: Leuven University Press.

- 1992. Essays and studies in New Testament textual criticism. Cordoba: Ediciones El Almendro.

Ellis, E E 1978a. Prophecy and Hermeneutic in Jude, in Ellis, E E (ed) 1978b:221236.

- (ed) 1978b. Prophecy and hermeneutic in Earty Christianity. Tübingen: Mohr.

Epp, E J 1976a. Towards the clarification of the term 'textual variant', in Elliott, J K (ed) 1976:153-173.

- 1976b. The eclectic method in New Testament textual criticism - Solution or symptom? HThR 69, 211-257. 
Fee, G D 1976. Rigorous or reasoned eclecticism - which? in Elliott, J K 1976:174197.

Feldman, L H (ed) 1965. Josephus: Jewish Antiquities, Books 18-20. London: Heinemann. (Loeb Classical Library.)

Flatt, D 1975. Thoroughgoing eclecticism as a method of textual criticism. Rest $Q$ 18, $102-114$.

Fuchs, E \& Reymond, P 1980. La dewxième épûre de Saint Pierre: L'épître de Saint Jude. Paris: Delachaux \& Niestlé.

Green, M 1987. The Second Epistle general of Peter and the general Epistle of Jude: An introduction and commentary. Leicester: Inter-Varsity.

H KAINH $\triangle$ IABHKH 1958. 2nd ed. London: British \& Foreign Bible Societies.

Haase, W (ed) 1988. Aufstieg und niedergang der Römischen Welt, Vol 2/25/5. Berlin: De Gruyter.

Hartin, P J \& Petzer, J H 1986. A South African perspective on the New Testament: Essays by South African New Testament scholars presented to Bruce Manning Metzger during his visit to South Africa in 1985. Leiden: Brill.

Hodges, Z C \& Farstad, A L (eds) 1982. The Greek New Testament according to the majority text. New York: Nelson.

Housman, A E 1922. The application of thought to textual criticism, in Diggle \& Goodyear (eds) 1972:1058-1069.

Jordaan, G J C 1980. Die beoordeling van woordorde-variante in die manuskripte van die Griekse Nuwe Testament, met besondere aandag aan die Evangelie volgens Lukas - 'n Metodologiese studie. Potchefstroom: Westvalia.

Kelly, J N D 1969. A commentary on the Epistles of Peter and of Jude. London: Black.

Kilpatrick, G D 1958. The transmission of the New Testament and its reliability. BiTr 9, 127-136.

--- 1961. The General Letters: A Greek-English diglot for the use of translators. (Unpublished fascicle for private circulation only.) London: British \& Foreign Bible Societies.

--- 1963. Atticism and the text of the New Testament, in Elliott J K (ed) 1990:1532.

--- 1965. The Greek New Testament text of today and the Textus Receptus, in Anderson \& Barclay (eds) 1965:189-206.

Kistemaker, S J 1987. New Testament commentay: Exposition of the epistles of Peter and the Epistle of Jude. Grand Rapids: Baker.

Knopf, R 1912. Die Briefe Petri und Judä. 7th ed. Göttingen: Vandenhoeck.

Kubo, S 1965. $p^{72}$ and the Codex Vaticanus. Salt Lake City: University of Utah. 
Kubo, S 1976. Textual relationships in Jude, in Elliott, J K (ed) 1976:276-282.

Lake, K (ed) 1953. Eusebius: The ecclesiastical history, 2 vols. London: Heinemann. (Loeb Classical Library.)

Lamb, W R M (ed) 1977. Plato: Laches, Protagoras, Meno, Euthydemus. London: Heinemann. (Loeb Classical Library.)

Louw, J P \& Nida, E A 1989. Greek-English Lexicon of the New Tesament based on semantic domains. Cape Town: Bible Society of South Africa.

Martini, C M 1974. Eclecticism and atticism in the textual criticism of the Greek New Testament, in Black \& Smalley 1974:149-156.

Merk, A 1964. Novum Testamentum Graece et Latine. 9th ed. Rome: Pontifical Biblical Institute.

Metzger, B M 1968. The text of the New Testament: Its transmission, comption and restoration. Oxford: Clarendon.

-- 1971. A textual commentary on the Greek New Testament. London \& New York: United Bible Societies.

Osburn, C D 1972. The text of Jude 22-23. ZNW 63, 139-144.

Page, T E (ed) 1944. Euripides: Ion, Hippolytus, Medea, Alcestis. London: Heinemann. (Loeb Classical Library.)

Petzer, J H 1986. The Papyri and New Testament textual criticism: Clarity or confusion? in Hartin \& Petzer (eds) 1986:18-32.

Schanz, J P 1983. Introduction to the sacraments. New York: Pueblo.

Sommerstein, A H (ed) 1983. The comedies of Aistophanes: Volume 4-Wasps. Warminster: Aris \& Phillips.

Stur, H A 1984. The Byzantine text-type and New Testament textual criticism. Nashville: Nelson.

Thackeray, H (ed) 1961. Josephus: The Jewish war, books 4-7. London: Heinemann. (Loeb Classical Library.)

Tischendorf, C 1872. Novum Testamentum Graece, vol 2. Leipzig: Hinrichs.

Turner, N 1963. A grammar of New Testament Greek, vol 3: Syntax. Edinburgh: Clark.

Voelz, J W 1989. The problem of meaning in texts. Neotestamentica 23, 33-43.

Vogels, H J 1949. Novum Testamentum Graece et Latine, vol 2. 4th ed. Freiburg: Herder.

- 1955. Handbuch der Teatkritik des Newen Testaments. 2nd ed. Bonn: Hanstein.

Von Soden, H F 1913. Die Schriften des Newen Testaments in ihrer altesten erreichbaren Textgestalt hergestell ouf Grund ihrer Textgeschichte, II teil: text mit apparat. Göttingen: Vandenhoeck. 
Watson, D F 1988. Invention, arrangement and style: Rhetorical criticism of Jude and 2 Peter. Atlanta: Scholars Press.

Westcott, B F \& Hort, F J A 1901. The New Testament in the original Greek. London: Macmillan.

Windisch, H 1951. Die katholischen Briefe. Tübingen: Mohr \& Siebeck.

Zerwick, M \& Grosvenor, M 1979. Grammatical analysis of the Greek New Testament. Rome: Pontifical Biblical Institute. 